\title{
Palikur traditional roundwood construction in eastern French Guiana: ethnobotanical and cultural perspectives
}

Clémence Ogeron ${ }^{1,2}$, Guillaume Odonne ${ }^{1 *} \mathbb{D}$, Antonia Cristinoi $^{3}$, Julien Engel ${ }^{4,5}$, Pierre Grenand ${ }^{1}$, Jacques Beauchêne ${ }^{6}$, Bruno Clair $^{2}$ and Damien Davy ${ }^{1}$

\begin{abstract}
Background: Palikur Amerindians live in the eastern part of French Guiana which is undergoing deep-seated changes due to the geographical and economic opening of the region. So far, Palikur's traditional ecological knowledge is poorly documented, apart from medicinal plants. The aim of this study was to document ethnobotanical practices related to traditional construction in the region.
\end{abstract}

Methods: A combination of qualitative and quantitative methods was used. Thirty-nine Palikur men were interviewed in three localities (Saint-Georges de l'Oyapock, Regina and Trois-Palétuviers) between December 2013 and July 2014. Twenty-four inventories of wood species used in traditional buildings were conducted in the villages, as well as ethnobotanical walks in the neighboring forests, to complete data about usable species and to determine Linnaean names.

Results: After an ethnographic description of roundwood Palikur habitat, the in situ wood selection process of Palikur is precisely described.

A total of 960 roundwood pieces were inventoried in situ according to Palikur taxonomy, of which 860 were beams and rafters, and 100 posts in 20 permanent and 4 temporary buildings. Twenty-seven folk species were identified. Sixty-three folk species used in construction were recorded during ethnobotanical walks. They correspond to 263 botanical species belonging to 25 families.

Posts in permanent buildings were made of yawu (Minquartia guianensis) (51\%) and wakap (Vouacapoua americana) (14\%). Beams and rafters were made of wood from Annonaceae (79\%) and Lecythidaceae (13\%) families. The most frequently used species were kuukumwi priye (Oxandra asbeckii), kuukumwi seyne (Pseudoxandra cuspidata), and pukuu (Xylopia nitida and X. cayennensis).

Conclusions: Although the Palikur's relationship with their habitat is undergoing significant changes, knowledge about construction wood is still very much alive in the Oyapock basin. Many people continue to construct traditional buildings alongside modern houses, using a wide array of species described here for the first time, along with the techniques used.

Keywords: Oyapock, Palikur, Traditional technological knowledge, Amazonia, Annonaceae, Sapotaceae, Non-timber forest products, Architecture

\footnotetext{
* Correspondence: guillaume.odonne@cnrs.fr

${ }^{1}$ LEEISA (Laboratoire Ecologie, Evolution, Interactions des Systèmes

Amazoniens), CNRS, Université de Guyane, IFREMER, 275 route de Montabo,

97300 Cayenne, France

Full list of author information is available at the end of the article
} 


\section{Background}

Numerous ethnobotanical works highlight the richness of ethnobotanical and ethno-ecological knowledge of Amerindian people. In French Guiana, this is particularly true of the Wayãpi Amerindians [29, 30]. Most of these works focus on medicinal plants $[33,47]$ and some advanced studies on technical plants used for crafts, e.g., basketry [15, 16], bows, and arrows [31], or for dyeing [34]. Conversely, the diversity of woody species used as building material for housing remains insufficiently explored [21, 30] even though the architectural relevance and perfect adaptation of the Guianan habitat to its environment has been demonstrated in several cultural groups $[1,10,38,54]$.

At the Amazonian level, roundwood is one of the most important non-commercial logging forest products still used today for subsistence by many forest-dwelling people $[18,61]$. Several ethnobotanical works claim that the wood of a wide range of species is suitable for construction, including all forms of permanent or temporary dwellings or any other structures (primarily smalldiameter roundwood used for posts and beams and sometimes sawn boards used for walls or for canoes) $[55,65]$. This obviously excludes any commercial timbers collected on an industrial scale. Indeed, depending on the community and location, the number of recorded species used for construction (with a diameter $>10 \mathrm{~cm}$ ) ranges from $3 \%$ of total woody species (Panare in Venezuela) to $56 \%$ (Arawak in Guyana) $[4,5,8,11,12$, $17,30,44,51,53,55,56,58,63,65]$. Some authors show that the choice of the species depends on the planned use, i.e., either as posts or for the framework, as these uses do not require the same degree of durability $[5,11,17,30,42$, $44,52,55,56,65]$. Despite this assessment, only one ethnobotanical study specifically focused on the use of wood in housing, combining an ethnographic description and a quantitative approach to the diversity of woody species used in a traditional Yanomami housing structure in Brazil [42]. The material, architectural, and, in some anthropological studies, symbolic dimensions of Amazonian habitats have been the main focus to date $[3,20,24,25$, $36]$. According to these references, and even if architectural typology and techniques are specific to each community, the general pattern of Amerindian construction in Amazonia (sensu lato, including in the Guiana shield) appears to be based on an erected roundwood framework, lashed together and thatched with palms $[5,19,20,24,25$, $36,38,42,44,54,56,65]$.

The Palikur people (Pahikwene) speak an Arawak language (pahikwaki) and originate from the northeast of Amapá (Brazil). The Palikur have been present in Amapá and the Oyapock region since the sixteenth century [32]. They now live in a region stretching from the central part of the coast of French Guiana to the extreme northeast of Amapá (Brazil). The Brazilian and French Palikur still maintain regular matrimonial and cultural exchanges. In 2001 , the total population was approximately 1800 people, of whom approximately 850 live in French Guiana [27]. A Palikur community has long been established in the district of Saint-Georges de l'Oyapock, including Trois-Palétuviers village since 1960, and their population is now estimated at around 500 people among a total population of approximately 2000 Palikur.

Recently, the lower Oyapock basin has undergone significant changes, especially since the construction of a national road in 2003, and changes will certainly be intensified as the bridge between French Guiana and Brazil opened [13, 28]. Despite major changes in habitat with the arrival of new building materials and a very old Western influence that dates back to the sixteenth century, the Palikur community is the only one in this area to conserve a traditional architectural typology as described by Mattioni [40], Nimuendaju [46], and Pérez [50]. Major technological and cultural shifts, evangelical influence, added to the process of assimilation in the 1960s, when traditional practices and ceremonial life were discouraged, led to deep modifications in their housing habits [27]. Like many other Amazonian peoples, the Palikur abandoned their former communitarian and semi-permanent housing for individual stilt houses based on neo-Amazonian models, which led to a new social and cultural order. Their settlement close to administrative centers also influenced their socio-cultural habits. Lastly, these transformations are related to several social housing programs that began in the early 1990s, when the Palikur slowly transformed their houses to resemble Western buildings [10]. Roundwood buildings have thus tended to lose their housing function, which is now more associated with concrete private houses. Traditional buildings are more and more limited to the role of annex buildings, dedicated to collective and communitarian life, or to daily tasks.

Due to the scarcity of data on traditional construction in north-eastern Amazonia and of in-depth studies on this topic and to prevent the loss of knowledge or its transformation due to the context of change, publishing the data gathered in the present study is important for both the Palikur and the scientific community.

To understand how the Palikur build traditional houses and which species they use, we (1) provide an ethnographic description of Palikur roundwood habitat, nomenclature, and techniques; (2) identify and quantify the diversity of woody species used for construction; and (3) compare our data with other Amazonian ethnobotanical studies.

\section{Methods}

Biodiversity and access to traditional knowledge

Traditional Palikur chiefs in the district of Saint-Georges de l'Oyapock were consulted at the beginning of the 
study and gave their verbal consent for our work. The chiefs were regularly informed about the progress of the project and were again consulted in September 2017 to obtain their agreement for publication of the results. Herbarium vouchers were collected in the national forest of "Régina-Saint-Georges de l'Oyapock" with the authorization of the French National Forestry Office (ONF) (no. 140523_02/MH/ML).

\section{Study site}

The survey was conducted in the district of SaintGeorges de l'Oyapock, from December to July 2014, in the village of Trois-Palétuviers in November, and in the village of Régina from April to May 2014 (Fig. 1). The forest cover area is quite homogeneous and mainly of the terra firme type, growing on crystalline rocky substrate, with predominance of species belonging to the Leguminosae (Caesalpinioideae) family [7, 35]. The climate is wet equatorial, and the average yearly rainfall is $3500 \mathrm{~mm}$, with a rainy season (December to July) and a dry season (August to November) [7].

\section{Open ended interviews}

In Palikur culture, construction is considered a male activity [46]. This gendered distribution led us to conduct a first set of open-ended interviews with Palikur men of an age to build their own houses. The interviews were

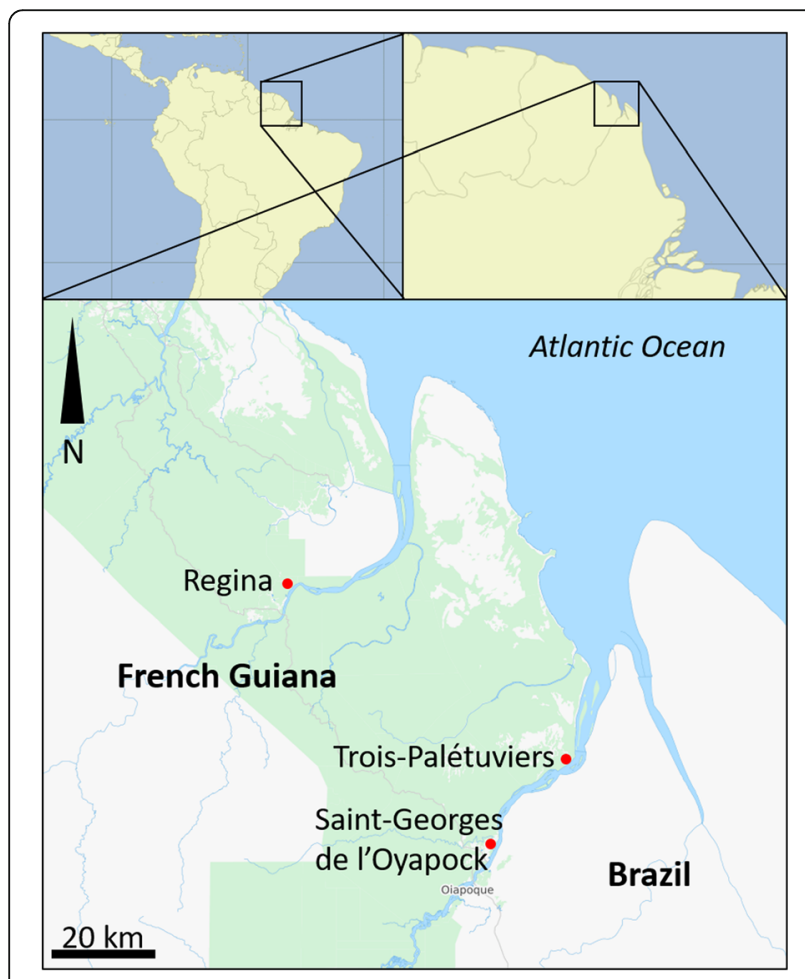

Fig. 1 Location of the study area conducted in the Palikur language (pahikwaki) if the interviewee so desired, otherwise in French.

\section{Structure nomenclature and techniques}

After identifying reliable informants in preliminary open-ended interviews, each category of wood components of each roundwood building was numbered and the Palikur names were recorded. Detailed drawings were used to facilitate dialog with informants. Each informant was interviewed separately to limit the influence of the other people present. Additional data such as the description of construction techniques and nomenclature were collected in semi-directed interviews. All the Palikur vocabulary was cross-checked in a final field campaign in January 2016.

\section{Inventories of construction wood}

Systematic quantitative surveys of the names of the wood used for each part of the frame were conducted using 24 constructions (14 in Saint-Georges de l'Oyapock, 8 in Trois-Palétuviers, and 2 in Régina) with the builders. Folk names in Palikur were used during this part of the survey. Assembly techniques, thatch materials, and the description of the wood were also recorded.

\section{Ethnobotanical walks}

Ethnobotanical walks were undertaken in the surrounding forest with 13 Palikur men to identify the species that corresponded to each folk name of wood previously identified as being used in the building. The men were paid as guides for this part of the work. The names of the species of wood names in Palikur and their uses were cross-checked to insure consensus. Herbarium vouchers, photographs, and GPS coordinates were collected for each tree.

\section{Plant collection and identification}

Voucher specimens were immediately preserved in 50\% ethanol until processing and incorporation in the herbarium of the "Institut de Recherche pour le Development" (IRD) in Cayenne, French Guiana (CAY). Identifications were made by C. Ogéron, J. Engel, and G. Odonne, assisted by professional botanists P. Delprete (Rubiaceae), R. Girault (generalist), E. Lucas (Myrtaceae), P. Maas (Annonaceae), and P. Petronelli (Guiana tree generalist). The taxonomic validity of species, genera, and families was checked according to APG IV [2] via the Taxonomic Name Resolution Service [14]. The supplementary ethnobotanical material (herbariums, folk names) was obtained from the CAY herbarium. These unpublished data had been collected in previous general Palikur ethnobotanical surveys conducted between 1978 and 2015. This involved a review of 261 herbarium vouchers deposited in the Cayenne herbarium 
and collected by P. Grenand, M. F. Prévost, G. Cremers, C. Moretti, H. Jacquemin, J. P. Lescure, M. E. Berton, D. Davy, G. Bourdy, J. J. Piolat, and S. Rostain (order of decreasing importance). One hundred seventy-five trees identified by J. Engel and P. Petronelli and named by one of the informants in a permanent forest plot located between Saint-Georges de l'Oyapock and Regina in a previous research project were added to the vouchers. These supplementary data were used to improve consensus between folk and botanical taxonomy.

\section{Data analysis}

A fidelity index (FI) was defined for each species of wood cited to quantify inventory data. The index was adapted from Friedman et al. [23] as follows: $\mathrm{Fl}=\mathrm{Np} / \mathrm{N}$ (where $\mathrm{Np}$ is the number of informants who independently claim a specific use of a wood in a building or in the forest and $\mathrm{N}$ is the total number of informants who use this wood for any use, to quantify the use consensus between all informants [41]).

\section{Results}

\section{Ethnographic description and typology of roundwood} Palikur habitat

Thirty-nine men were interviewed (21 from Saint-Georges de l'Oyapock, 13 from Trois-Palétuviers, and 5 from Régina), representing approximately $20 \%$ of the adult Palikur male population of north-eastern French Guiana. The average age of the surveyed population was 50 (ages ranged from 20 to 77 ).

According to the informants, Palikur used to live in circular collective houses (payt masikahaki) covered by a conical roof, thatched with palms and extending to the ground, as also reported by Mattioni [40] and Pérez [50]. The structure of the roof recalls that of the nest of the motye masik wasp, Apoica pallida (Vespidae). However, archives of the seventeenth and eighteenth centuries only evoke rectangular collective houses on stilts. The first architectural type has now disappeared and has been replaced by rectangular, open buildings, topped by a ridge. These buildings have a wooden framework made of small diameter roundwood, close to the generic type of housing in Amazonia. When the Palikur from Saint-Georges de l'Oyapock occupied the inundated savannas and forested islands of the Arucauá in Brazil, they built houses on stilts. These had a raised floor (payt avaakap) made of ax-split palm tree stipes or of wooden planks (paak) cut with European saws [40, 46]. A trunk with carved steps (ara$y b u$ ) was used as a ladder to access the living area [40]. Today, this kind of housing is only found in small settlements located near rivers and marshes in Brazil. Other houses that were erected on firm ground had a dirt floor. The second type is the main form found in eastern French Guiana today. Since Palikur settled permanently in Saint-
Georges de l'Oyapock in the 1960s, housing has been continually changing, notably due to relocation programs that started in the 1990s. Traditional housing is progressively being replaced by contemporary, individual, concrete houses (payt bataka). These are prefabricated, concrete, one-story houses, sometimes closed with wood cladding, covered with a corrugated iron roof (avinvit sivariptiye). The last houses (payt himeket) that still have a raised floor are closed individual ones. They are built on stilts, and the style is between that of traditional Palikur roundwood houses and Amazonian cabocla houses [50]. The frame still has the traditional appearance, but the round posts have been replaced by sawn wood. Despite these changes, roundwood housing is still definitely present.

Permanent roundwood Palikur housing groups four distinct functional types, of which two are still dedicated to community life (Table 1). One of these buildings is where meetings, ceremonies, councils, and cultural activities take place (payt pahadrunket, Fig. 2a). The other is used by the families to make roasted cassava flour (payt ihevinwa, Fig. 2b). Although these buildings are sometimes located in the plantations themselves, nowadays they are usually associated with the home. Their architecture is traditional with a simple hip roof, with or without apses, including triangular vent holes (miokye) both to allow the smoke to escape and to ventilate the structure.

In addition to these buildings, there are individual buildings with gable roofs, including a handful of homes (payt himeket) built on stilts (Fig. 3a), whose flooring is at a height of $80 \mathrm{~cm}$ above the ground. They are sealed with wood cladding (pitimka) obtained from industrial sawmills in the neighboring Brazilian city of Oiapoque. One of the gables is often extended to form a lean-to (payt adaka), added as protection against the prevailing wind [40]. A small cooking (payt sakehweket) or meat grilling (payt tevweyeket) hut is often added and is sometimes used as a resting place (Fig. 3b).

Gable roof shelters found in plantations (payt pawkavinwa) are built to last for short periods of time (Fig. 4), and their structure is lighter. Temporary buildings also include individual shelters used on hunting trips (payt timuvugaib, meaning literally Crax alector bird tail like shelter), as well as bigger ones used as collective housing during hunting trips (payt wewvaki). Aviaries (takaak gavin) and kennels (peu gavin) are also light buildings.

\section{Construction of Palikur roundwood permanent buildings}

All the materials (wood, bonds, palms) used in a roundwood building are of plant origin and are harvested in the neighboring forest.

\section{In situ tree selection, recognition, and harvest}

The recognition and choice of trees in the forest is a progressive process, involving several cognitive criteria. 
Table 1 Palikur habitat names and their meaning

\begin{tabular}{|c|c|c|c|}
\hline Palikur name & Etymology & English name & Type \\
\hline Payt hihevinwa (syn.: payt hihe avin) & $\begin{array}{l}\text { Payt: house } \\
\text { Hihe: pan }\end{array}$ & Cassava house & Permanent \\
\hline Payt pahadrunket (syn.: payt kayket) & $\begin{array}{l}\text { Payt: house } \\
\text { Pahadrunka: meeting } \\
\text { Kayka: to dance }\end{array}$ & Meeting house & Permanent \\
\hline Payt himeket & $\begin{array}{l}\text { Payt: house } \\
\text { Himekne: to sleep }\end{array}$ & Sleeping house & Permanent \\
\hline Payt sakehweket (syn:: payt terweyeket) & $\begin{array}{l}\text { Payt: house } \\
\text { Sakehwene: to cook, to boil } \\
\text { Terwene: to roast }\end{array}$ & $\begin{array}{l}\text { Cooking house } \\
\text { Roasting house }\end{array}$ & Permanent \\
\hline Payt pawkavinwa & $\begin{array}{l}\text { Payt: house } \\
\text { Pawka: far }\end{array}$ & Plantation house & Temporary \\
\hline Payt timuvugaib & $\begin{array}{l}\text { Payt: house } \\
\text { Timuvu: hocco (bird) Crax alector } \\
\text { Gayb: tail }\end{array}$ & Hocco's tail shelter (small hunting shelter) & Temporary \\
\hline Payt wewraki & $\begin{array}{l}\text { Payt: house } \\
\text { Wewvene: to hunt }\end{array}$ & Hunting shelter & Temporary \\
\hline Pew gavin & $\begin{array}{l}\text { Pew: dog } \\
\text {-Vin: house }\end{array}$ & Kennel & Temporary \\
\hline Takaak gavin & $\begin{array}{l}\text { Takaak: chicken } \\
\text {-Vin: house }\end{array}$ & Aviary & Temporary \\
\hline
\end{tabular}

Syn. synonym

The first criterion depends on the selected use. For posts, as the number of species used is small, the selection is first based on identification of the species, then on the rectitude and the diameter of the trunk (> $20 \mathrm{~cm}$ ). Concerning roundwood for the frame, the first criterion is the trunk geometry. Palikur prefer smalldiameter trees (around $15 \mathrm{~cm}$ maximum), with both a straight and cylindrical trunk (as opposed to angular, buttressed trunks). The hardness of the wood is first estimated by the sound produced when the trunk is hit with a machete. Hardwoods are most prized and are recognizable by the clear sound they emit and by the fact that they offer greater resistance to the machete's blade. Species are also often identified by making a slash in the bark and trunk wood with a machete. Identification involves observation of various phenotypic traits: trunk shape, wood and bark color, texture, smell, taste, and presence of exudates.
Trees are preferably felled in the waning moon phase, which is thought to prevent infestation by xylophagous insects. The most frequently cited woodborers are termites (mun) (genera Heterotermes, Coptotermes, Nasutitermes) or wood-eating beetles (uvis) (genera Lyctus, Bostryches, Anobium, Scolytes). Wood cut during this period is also thought to be less likely to split. Trees are cut down with axes or machetes, but chainsaws are progressively replacing them.

\section{Wood transformation process}

The straight cylindrical part of the trunk, measuring from 10 to $15 \mathrm{~m}$, is prepared in situ. The branches are removed with a machete, and then, the bark is stripped from the boles. A machete is used for Annonaceae and Lecythidaceae whose barks are easy to strip off. The blade is inserted along the cambium between the wood and the bark. For the Chrysobalanaceae, which have a

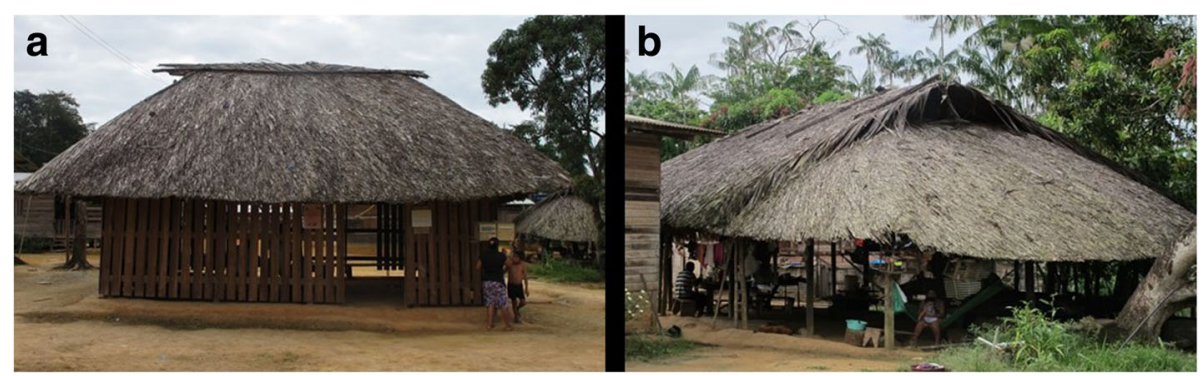

Fig. 2 Left, a ceremonial building with a simple hip roof. Right, b simple hip building with apses, used for cassava flour preparation 


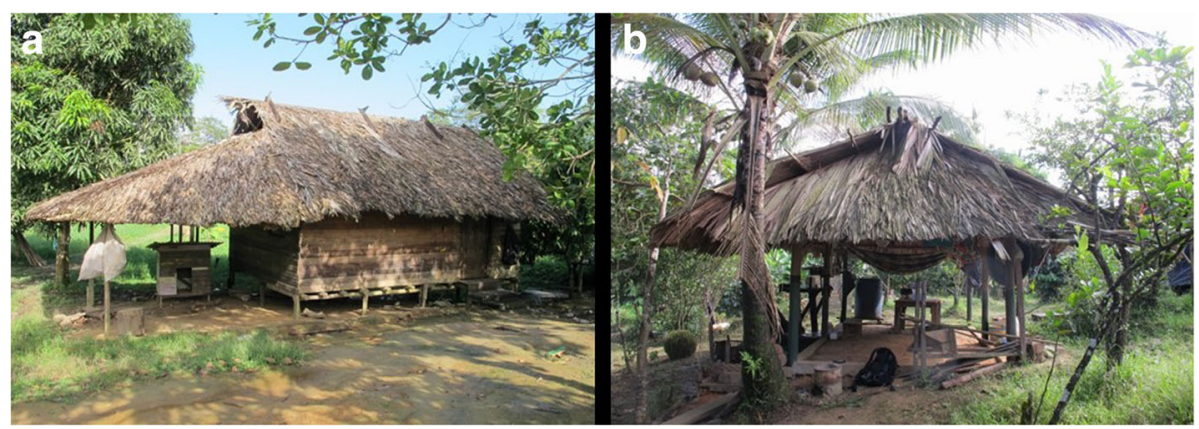

Fig. 3 Left, a living house on stilts. Right, b cooking and resting building annexed to a house

more adhesive bark, the bole is hit with a large stick and scratched with the blade of the machete to peel off the bark. The aim of these processes is to prevent attacks by wood-eating pests and to allow the wood to dry and harden more quickly. In temporary buildings, the bark is sometimes not stripped off, as it peels off spontaneously after drying. The boles are then carried by hand to the construction site, with the assistance of a motor vehicle if available. They are then cut into pieces of the appropriate length for the desired building. These steps are always carried out on green wood, as it hardens and deforms while drying. Depending on the species used, the pieces destined to be used as posts may have their sapwood (a gasisin) (peripheral, non-durable wood) removed with an ax, conserving only the heartwood ( $\tilde{a}$ gayakni). This finishing step was observed only once and aims to prevent the wood rotting and to avoid insect attacks.

\section{Material processing, assembly techniques, and structure nomenclature}

Once the location of the building has been chosen, the first step is setting up the vertical frame (Fig. 5). The length between two posts is measured in fathoms, i.e., the space between the two hands, arms open wide. Posts

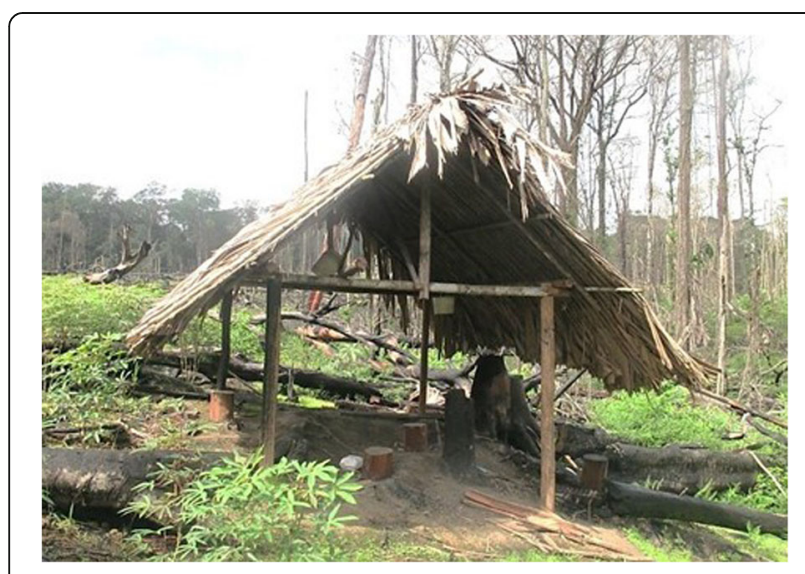

Fig. 4 Light shelter in a cassava field
(10-15 cm in diameter) are buried to a depth of 50$80 \mathrm{~cm}$ in holes in the earth floor. Girders are placed on top of the posts in mid-wood notches (araybu). The structural elements that rely on these are tied together and secured by square or diagonal lashing (Fig. 6). Their names in Palikur are listed in Table 2.

The building is thatched with palms from Manicaria saccifera, also harvested during the waning moon phase to prevent attacks by xylophagous insects. The leaves are folded longitudinally and piled starting from the bottom and working toward the top of the roof. The midrib oriented vertically to allow water to run freely. The leaves are lashed to the battens by their midrib. The tighter the leaves, the longer the roof will last. A supplementary layer of palms is placed horizontally along the top to seal the ridge and held in place by wooden sticks stuck into the roof.

\section{Species used in the composition of building}

Inventories of buildings under construction resulted in a total of 960 roundwood pieces, divided between 100 posts (85 permanents and 15 temporaries; see Table 3 ) and 860 frame pieces (783 permanents and 77 temporaries; see Table 4) in 24 buildings (20 permanent and 4 temporary). Twenty-seven folk wood taxa were recorded (Tables 3 and 4). Among these 24 buildings, 46\% (11/24) had a frame made of roundwood only.

Ethnobotanical walks resulted in 63 folk taxa from 233 herbarium vouchers given by 13 informants, potentially used in buildings (resulting in 36 folk taxa more than in inventories of buildings/of buildings under construction?). To improve the scientific and Palikur taxonomical correlation, we used 261 supplementary herbarium vouchers as well as in-field identification of 175 specimens, giving a total of 699 specimens from 25 botanical families (Table 5).

In Palikur ethnobotany, correlations between botanical and folk taxa are particularly difficult to establish. Only $25 \%$ of the folk species matched a botanical species in a one-to-one correspondence, following Berlin's nomenclature (1993). Three quarters of the folk species refer to groups of botanical species, illustrating a pattern Berlin 

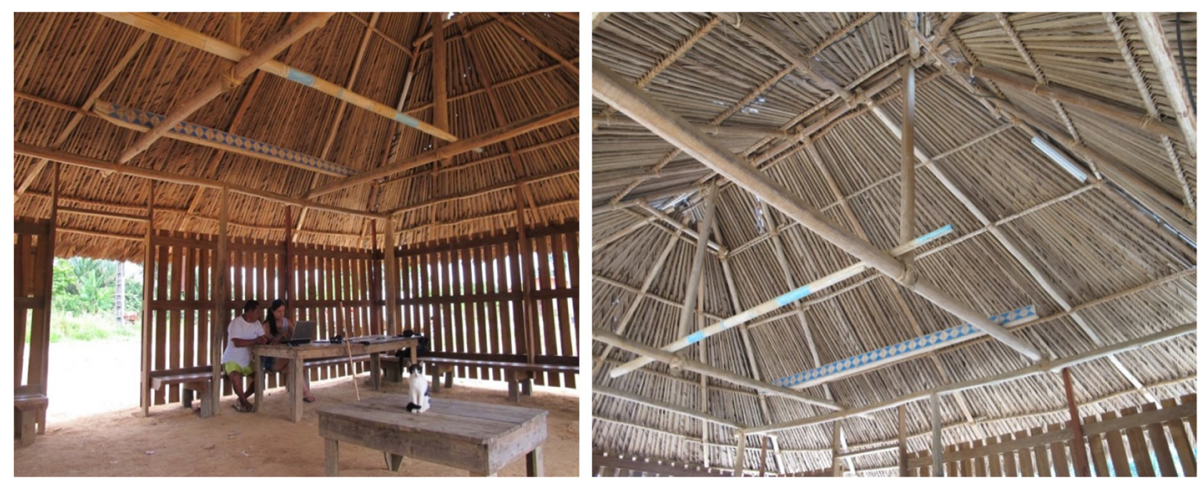

Fig. 5 Ceremonial building at Esperance village, from the inside (same building as in Fig. 2a)

[9] describes as under differentiation: $25 \%$ of the total refer to different species in a single genus, $48 \%$ refer to species in different genera in the same botanical family, and $2 \%$ refer to species in different families (Table 5).

\section{Wood preferences and selection criteria}

Posts Field surveys revealed that $65 \%(55 / 85)$ of the woods cited as being used for posts in permanent buildings belong to two botanical species (Table 3): Minquartia guianensis, 51\% (43/85), and Vouacapoua americana, $14 \%(12 / 85)$. Young, straight, and fluted trunks of $M$. guianensis and $V$. americana are highly appreciated by the Palikur for their hardness, their durability, and their resistance to rot and to wood-eating insects. The wood from $V$. americana is so highly valued by them that it has become the prototype species for posts: wakap refers both to the term "post" and to the species. Wood from the genera Eschweilera and Lecythis in the Lecythidaceae family account for $13 \%(11 / 85)$ of the permanent posts, even though the Palikur are aware they are less durable as far as rotting and xylophages are concerned. Aspidospermum excelsum wood is cited for $7 \%(6 / 85)$ of the permanent posts and is also well known for crafting paddles. The hard heavy wood from several Chrysobalanaceae species (Licania, Hirtella, Couepia, named bukutru gatew) is also used but to a lesser extent, due to their tendency to split when dropped and because their bark is difficult to peel off. Several Pouteria (kuyaw kamwi duwõ and tukuyuy kamwi) are used for posts as second choice (7\%; $6 / 85$ for both).

Beams and rafters Most of the elements of the permanent building frame come from two families: Annonaceae (79\%; 681/860) and Lecythidaceae (13\%; 112/860). Among the Annonaceae, the most frequently used are Oxandra asbeckii, Pseudoxandra cuspidata, Xylopia nitida, and $X$. cayennensis.

The two Xylopia species are preferentially used for thin pieces of the framework, and pukuu accounts for $78 \%$ of the battens. Among the Lecythidaceae, Lecythis persistens, Eschweilera cf. coriacea, E. sagotiana, and L. poiteaui are the most frequently used. The Palikur justify the use of Annonaceae because of their long straight trunks that are ideal for long span beams. Unlike the wood from Lecythidaceae, the Annonaceae wood does not split, either when being felled or while drying. It is also lighter and more flexible than other woods of the

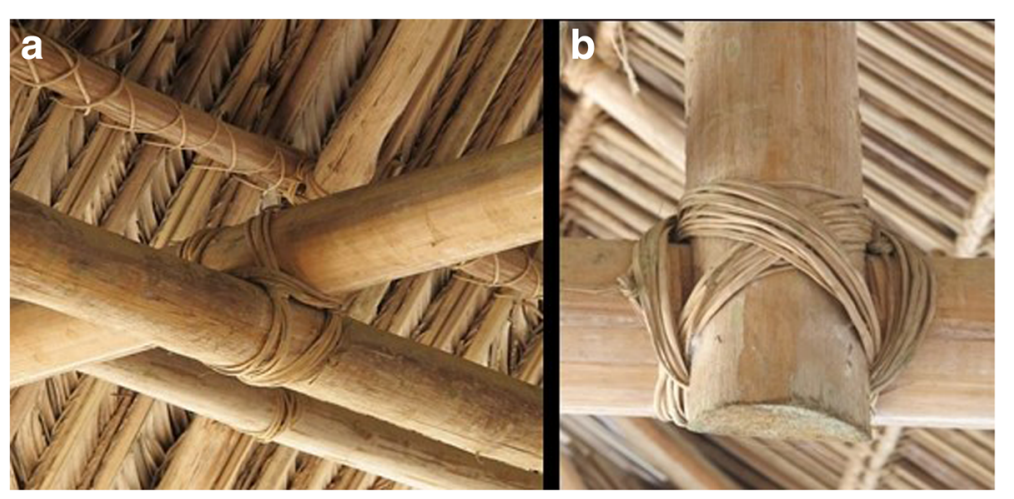

Fig. 6 Lashings (wanaka) with M. saccifera palm cover in the background. Left, a square lashings. Right, b diagonal lashings 
Table 2 Palikur names of structural elements and their English equivalent

\begin{tabular}{ll}
\hline Structure element & Palikur name \\
\hline Post & Wakap \\
Bridging beam & Ayabwi dahagbukya wakap \\
Tie beam & Adaap \\
Crown post or king & Akoksa \\
post & \\
Lower ridge piece & Ayabwi dahagbukya akoksa \\
Upper ridge piece & Ayabwi avugekuya \\
Common rafter & Avayta \\
Roof rafter & Avayta amagtongitak \\
Angle rafter & Avayta savogene \\
Upper tie beam & Atawkan adah kamaxne avayta \\
Batten of roofing & amagtõgitak \\
Wind brace & Akanwapti \\
Hipped roof & Asugetni \\
Roof slope & Payt amagtõ \\
Mid wood notches & Payt amuwi \\
Lashings & Araybu \\
\hline
\end{tabular}

same size, making framing easier and enabling the construction of apses. After drying, kuukumwi wood hardens and becomes very resistant. Annonaceae wood is generally perceived as being more resistant to xylophagous insects than Lecythidaceae wood whose sapwood is seriously attacked by wood-eating beetle larvae.

Nevertheless, the two families share the advantage of having fibrous bark, which is easily peeled off in wide longitudinal strips, thereby facilitating preparation. Easy debarking is a technical and esthetic selection criterion for building use. Indeed, 90\% (860/960) of the pieces of wood counted were bare. Debarking is almost systematic for permanent buildings (98\%; $850 / 868$ ), while less attention is paid to debarking in the case of temporary buildings $(11 \% ; 10 / 92)$. The wood for provisional buildings is selected with less care. Availability in the vicinity of the building site is more important than the technical qualities of the wood, meaning brittle wood or wood that is hard to debark is also used. This is the case for Diospyros spp., which accounted for 22\% (17/77) of all the pieces of wood used in temporary buildings counted.

Table 3 Wood names of the 100 inventoried posts in permanent or temporary buildings (wood ranked according to the total number of citation per use)

\begin{tabular}{|c|c|c|c|c|}
\hline Botanic family & Palikur name & Rank & Permanent (total 85) & Temporary (total 15) \\
\hline \multirow[t]{3}{*}{ Annonaceae } & Pukuu (seyne) & 7 & 2 & 0 \\
\hline & Kuukumwi (priye) & 7 & 1 & 1 \\
\hline & Kunkumwi (seyne) & 8 & 1 & 0 \\
\hline Apocynaceae & Isuu ã & 3 & 6 & 0 \\
\hline Chrysobalanceae & Bukutru gatew & 3 & 0 & 6 \\
\hline Erythroxylaceae & Yawknabui duwõ & 7 & 2 & 0 \\
\hline \multirow[t]{4}{*}{ Fabaceae } & Ãjelik & 8 & 1 & 0 \\
\hline & Arey avaini & 8 & 0 & 1 \\
\hline & Miumiu & 8 & 0 & 1 \\
\hline & Wakap & 2 & 12 & 0 \\
\hline Goupiaceae & Pasis & 8 & 0 & 1 \\
\hline \multirow[t]{3}{*}{ Lecythidaceae } & Avun & 6 & 2 & 0 \\
\hline & Kwatri (waxriune) seyne & 5 & 6 & 0 \\
\hline & Yawknabwi (seyne) & 6 & 3 & 0 \\
\hline Myristicaceae & Wahusi (waxriuno duwõ) & 7 & 1 & 0 \\
\hline Myrtaceae & Awaw & 8 & 1 & 0 \\
\hline Olacaceae & Yawu & 1 & 43 & 0 \\
\hline Rubiaceae & Kinuwup & 7 & 2 & 0 \\
\hline \multirow[t]{3}{*}{ Sapotaceae } & Balata kamwi & 8 & 1 & 0 \\
\hline & Kuyau (kamwi) duwõ & 4 & 0 & 5 \\
\hline & Tukuyuy kamwi & 8 & 1 & 0 \\
\hline
\end{tabular}


Table 4 Wood names of the 860 components of frameworks inventoried in permanent or temporary buildings (wood ranked according to the total number of citation per use)

\begin{tabular}{|c|c|c|c|c|c|c|c|c|c|c|c|}
\hline Botanic family & Palikur name & Rank & $\begin{array}{l}\text { Permanent } \\
\text { (total 783) }\end{array}$ & $\begin{array}{l}\text { Temporary } \\
\text { (total 77) }\end{array}$ & Beam & $\begin{array}{l}\text { Tie } \\
\text { beam }\end{array}$ & $\begin{array}{l}\text { Ridge } \\
\text { piece }\end{array}$ & $\begin{array}{l}\text { Crown } \\
\text { post }\end{array}$ & $\begin{array}{l}\text { Common } \\
\text { rafter }\end{array}$ & Batten & $\begin{array}{l}\text { Wind } \\
\text { brace }\end{array}$ \\
\hline \multirow[t]{4}{*}{ Annonaceae } & Kunkumwi (priye) & 1 & 210 & 11 & 14 & 21 & 13 & 11 & 71 & 84 & 7 \\
\hline & Kunkumwi (seyne) & 2 & 230 & 13 & 11 & 17 & 12 & 18 & 68 & 103 & 14 \\
\hline & Pukuu (seyne) & 3 & 200 & 17 & 2 & 3 & 1 & 12 & 27 & 170 & 2 \\
\hline & Kigiksau & 8 & 10 & 0 & 2 & 3 & 2 & - & 3 & - & - \\
\hline \multirow[t]{2}{*}{ Chrysobalanceae } & Inutawviye & 7 & 10 & 0 & 2 & - & 8 & - & - & - & - \\
\hline & Bukutru gatew & 9 & 0 & 9 & - & 3 & - & 2 & 1 & 1 & 2 \\
\hline Ebenaceae & Miret & 6 & 0 & 17 & - & - & 2 & - & 10 & 4 & 1 \\
\hline Bignoniaceae & Kwik & 14 & 1 & 0 & - & - & - & - & - & - & 1 \\
\hline Erythroxylaceae & Yawknabwi duwõ & 10 & 8 & 0 & - & 7 & 1 & - & - & - & - \\
\hline Goupiaceae & Pasis & 14 & 1 & 0 & - & - & - & - & - & 1 & - \\
\hline \multirow[t]{3}{*}{ Lecythidaceae } & Avun & 5 & 11 & 7 & 4 & 7 & 2 & - & 1 & 4 & - \\
\hline & $\begin{array}{l}\text { Kwatri (waxriune) } \\
\text { seyne }\end{array}$ & 10 & 6 & 0 & - & - & - & - & - & 6 & - \\
\hline & Yawknabwi (seyne) & 4 & 88 & 0 & 8 & 14 & 7 & 2 & 40 & 16 & 1 \\
\hline Moraceae & Pairi (seyne) & 14 & 0 & 1 & - & - & - & 1 & - & - & - \\
\hline Myristicaceae & $\begin{array}{l}\text { Wahusi (waxriuno } \\
\text { duwõ) }\end{array}$ & 12 & 3 & 0 & - & - & - & - & 3 & - & - \\
\hline Myrtaceae & Awaw & 13 & 2 & 0 & - & - & 1 & - & - & - & 1 \\
\hline \multirow[t]{2}{*}{ Sapotaceae } & balata (duwõ) & 11 & 3 & 0 & - & - & - & - & 2 & 1 & - \\
\hline & $\begin{array}{l}\text { Kuyaw (kamwi) } \\
\text { duwõ }\end{array}$ & 13 & 0 & 2 & 1 & - & - & - & 1 & - & - \\
\hline
\end{tabular}

\section{Lash and thatch materials}

Today, nails are increasingly used to assemble frame elements. Only two out of 25 buildings were made from roundwood lashed together without nails. Lashings are made of aerial roots of two hemi-epiphytic species: Thoracocarpus bissectus (Cyclanthaceae) and Heteropsis flexuosa (Araceae). Roots of T. bissectus are considered to be stronger than those of $H$. flexuosa, but they have to be soaked underwater for 2 to 3 weeks before being peeled and used, while the latter are easier to peel [15]. The roots are split longitudinally before use.

Among the 25 buildings inventoried, 23 have a thatched roof and two have corrugated iron roofs. The thatching material is always made from the palms of $M$. saccifera (Table 6). The palms are mainly lashed to the battens (52\%; 12/23). Lashings are mainly made from $T$. bissectus (Table 6), followed by H. flexuosa or from splints of Ischnosiphon obliquus (Marantaceae). Today, these techniques are slowly being replaced by nails $(48 \% ; 11 / 23)$.

It is noteworthy that the use of the small Geonoma baculifera, which is widespread in French Guiana, is well known to the Palikur, but their palms only measure $60 \times 20 \mathrm{~cm}$, whereas Manicaria palms measure more than $300 \times 100 \mathrm{~cm}$, so Geonoma baculifera is only very occasionally used in our study area (Additional file 1).

\section{Perception of traditional housing}

Nearly half the people who expressed their opinion on this point $(48 \%$; 10/21) consider the roundwood housing to be more comfortable from a bioclimatic point of view than concrete buildings. Roundwood housing optimizes ventilation of the structure and allows smoke to escape, which is why the Palikur use it for daily tasks in addition to their living house. It is nevertheless described as cold to sleep in at night. Others use roundwood to build because it is free, as the raw material is collected in neighboring forests without the need for technical equipment (38\%; 8/21), for its appearance $(33 \% ; 7 / 21)$, and lastly for its convenience $(19 \% ; 4 / 21)$. It should be noted that $84 \%$ $(33 / 39)$ of the Palikur interviewed have no other income than minimum social benefits. But they do have regular access to forest products as the vast majority still practice slash and burn agriculture, fishing, hunting, or harvesting in the forest (94\%; 37/39).

\section{Discussion}

Building techniques

The building techniques and materials used by the Palikur are common to many Amazonian peoples [24, 25, 43], but they are changing with the liberal economic system and access to consumer goods [39]. Settlement influences housing structure in two main ways. The first is the search 
Table 5 Botanical names of the most frequently collected species

\begin{tabular}{|c|c|c|c|c|c|}
\hline \multirow[t]{2}{*}{$\begin{array}{l}\text { Botanic family } \\
\text { (main palikur name) }\end{array}$} & \multirow[t]{2}{*}{ Botanical name ${ }^{a}$} & \multirow[t]{2}{*}{$\begin{array}{l}\text { Reference voucher } \\
\text { specimen }^{b}\end{array}$} & \multirow[t]{2}{*}{$\begin{array}{l}\text { Correspondence botanical } \\
\text { species/ethnospecies }\end{array}$} & \multicolumn{2}{|c|}{ Fidelity level of use } \\
\hline & & & & Post & Frame \\
\hline \multicolumn{6}{|l|}{ Annonaceae } \\
\hline \multirow[t]{4}{*}{ Kigiksaw } & Guatteria punctata (Aubl.) R.A. Howard & $\mathrm{CO} .80$ & $4 / 13$ & $0 / 3$ & $3 / 3$ \\
\hline & Guatteria wachenheimii Benoist & MC.392 & $3 / 13$ & & \\
\hline & Anaxagorea phaeocarpa Mart. & CO.281 & $2 / 13$ & & \\
\hline & Guatteria anteridifera Scharf \& Maas & MC.50 & $2 / 13$ & & \\
\hline \multirow[t]{5}{*}{ Kunkumwi priye } & Oxandra asbeckii (Pulle) R.E. Fr. & CO.1 & $16 / 29$ & $1 / 6$ & $6 / 6$ \\
\hline & Guatteria wachenheimii Benoist & CO.320 & $4 / 29$ & & \\
\hline & Unonopsis rufescens (Baill.) R.E. Fr. & CO.65 & $3 / 29$ & & \\
\hline & Guatteria anteridifera Scharf \& Maas & CO.266 & $2 / 29$ & & \\
\hline & Pseudoxandra cuspidata Maas & MC.663 & $2 / 29$ & & \\
\hline Kunkumwi seyne & Pseudoxandra cuspidata Maas & CO.13 & $5 / 5$ & $0 / 5$ & $5 / 5$ \\
\hline \multirow[t]{2}{*}{ Pukuu (seyne) } & Xylopia nitida Dunal & $\mathrm{CO} .40$ & $6 / 9$ & $0 / 3$ & $3 / 3$ \\
\hline & Xylopia cayennensis Maas & Gr. 1677 & $3 / 9$ & & \\
\hline \multicolumn{6}{|l|}{ Apocynaceae } \\
\hline Isuu ã & Aspidosperma excelsum Benth. & MC.24 & $2 / 2$ & $1 / 1$ & $0 / 1$ \\
\hline Gõngo & Geissospermum laeve (Vell.) Miers & CO.118 & $3 / 3$ & $1 / 1$ & $1 / 1$ \\
\hline Pakih etni & Parahancornia fasciculata (Poir.) Benoist & Gr.3064 & $4 / 4$ & $0 / 2$ & $2 / 2$ \\
\hline \multicolumn{6}{|l|}{ Bignoniaceae } \\
\hline Kwik & Handroanthus serratifolius (Vahl) S.O.Grose & Gr.3109 & $2 / 2$ & & \\
\hline \multicolumn{6}{|l|}{ Burseraceae } \\
\hline \multirow[t]{4}{*}{ Ahuwahu } & Protium opacum Swart & L.796 & $5 / 19$ & $0 / 3$ & $3 / 3$ \\
\hline & Protium tenuifolium (Engl.) Engl. & Pr.Gr.4336 & $3 / 19$ & & \\
\hline & Protium apiculatum Swart & Gr.1583 & $3 / 19$ & & \\
\hline & Protium morii D.C. Daly & MC.456 & $2 / 19$ & & \\
\hline \multirow[t]{4}{*}{ Marinaiwa } & Protium altsonii Sandwith & MC.26 & $3 / 13$ & $0 / 3$ & $3 / 3$ \\
\hline & Protium gallicum D.C. Daly & Gr.2143 & $3 / 13$ & & \\
\hline & Protium decandrum (Aubl.) Marchand & MC.109 & $2 / 13$ & & \\
\hline & Protium trifoliolatum Engl. & MC.117 & $2 / 13$ & & \\
\hline \multirow[t]{3}{*}{ Sirasira } & Protium decandrum (Aubl.) Marchand & MC.22 & $3 / 14$ & $0 / 4$ & $4 / 4$ \\
\hline & Tetragastris panamensis (Engl.) Kuntze & Gr.1858 & $2 / 14$ & & \\
\hline & Protium subserratum (Engl.) Engl. & Gr.3125 & $2 / 14$ & & \\
\hline \multicolumn{6}{|l|}{ Chrysobalanaceae } \\
\hline \multirow[t]{6}{*}{ Bukutru gatew } & Licania alba (Bernoulli) Cuatrec. & CO.345 & $12 / 40$ & $5 / 5$ & $5 / 5$ \\
\hline & Couepia caryophylloides Benoist & CO.356 & $4 / 40$ & & \\
\hline & Hirtella bicornis Mart. \& Zucc. & CO.293 & $4 / 40$ & & \\
\hline & Hirtella glandulosa Spreng. & $\mathrm{CO} .334$ & $2 / 40$ & & \\
\hline & Licania densiflora Kleinhoonte & CO.144 & $2 / 40$ & & \\
\hline & Licania membranacea Sagot ex Laness. & Pr.Gr.4370 & $2 / 40$ & & \\
\hline Inutauviye & Licania heteromorpha Benth. & CO.229 & $7 / 16$ & $2 / 2$ & $2 / 2$ \\
\hline \multicolumn{6}{|l|}{ Clusiaceae } \\
\hline \multirow[t]{2}{*}{ Kwatri (waxriune) duwõ } & Tovomita brevistaminea Engl. & CO.292 & $2 / 10$ & $3 / 3$ & $3 / 3$ \\
\hline & Tovomita choisyana Planch. \& Triana & CO.29 & $2 / 10$ & & \\
\hline
\end{tabular}


Table 5 Botanical names of the most frequently collected species (Continued)

\begin{tabular}{|c|c|c|c|c|c|}
\hline \multirow[t]{3}{*}{$\begin{array}{l}\text { Botanic family } \\
\text { (main palikur name) }\end{array}$} & \multirow{2}{*}{$\begin{array}{l}\text { Botanical name }^{a} \\
\text { Tovomita sp. } 1\end{array}$} & \multirow{2}{*}{$\begin{array}{l}\begin{array}{l}\text { Reference voucher } \\
\text { specimen }^{\text {b }}\end{array} \\
\text { CO.82 }\end{array}$} & \multirow{2}{*}{$\begin{array}{l}\text { Correspondence botanical } \\
\text { species/ethnospecies } \\
2 / 10\end{array}$} & \multicolumn{2}{|c|}{ Fidelity level of use } \\
\hline & & & & & \\
\hline & Tovomita sp. 2 & CO.17 & $2 / 10$ & & \\
\hline$T i$ & Symphonia globulifera L.f. & CO.57 & $4 / 5$ & $0 / 2$ & $2 / 2$ \\
\hline \multirow[t]{3}{*}{ Wakukwa tiranõ } & Garcinia macrophylla Mart. & Gr.2128 & $3 / 7$ & $0 / 1$ & $1 / 1$ \\
\hline & Garcinia benthamiana (Planch. \& Triana) Pipoly & MC.343 & $2 / 7$ & & \\
\hline & Garcinia madruno (Kunth) Hammel & Gr.3119 & $2 / 7$ & & \\
\hline \multicolumn{6}{|l|}{ Ebenaceae } \\
\hline \multirow[t]{3}{*}{ Miret } & Diospyros carbonaria Benoist & MC.70 & $3 / 13$ & $0 / 1$ & $1 / 1$ \\
\hline & Diospyros dichroa Sandwith & Gr.3157 & $3 / 13$ & & \\
\hline & Diospyros cavalcantei Sothers & MC.46 & $2 / 13$ & & \\
\hline \multicolumn{6}{|l|}{ Elaeocarpaceae } \\
\hline Waaduk (seyne) & Sloanea laxiflora Spruce ex Benth. & CO.286 & $5 / 5$ & $0 / 1$ & $1 / 1$ \\
\hline \multicolumn{6}{|l|}{ Erythroxylaceae } \\
\hline Yawknabwi duwõ & Erythroxylum amplum Benth. & Gr.Pr.2050 & $4 / 4$ & $2 / 3$ & $3 / 3$ \\
\hline \multicolumn{6}{|l|}{ Goupiaceae } \\
\hline Pasis & Goupia glabra Aubl. & Co.18 & $5 / 5$ & $2 / 3$ & $3 / 3$ \\
\hline \multicolumn{6}{|l|}{ Ixonanthaceae } \\
\hline Yawu wahuyo & Cyrillopsis paraensis Kuhlm. & CO.46 & $2 / 2$ & $5 / 5$ & $0 / 5$ \\
\hline \multicolumn{6}{|l|}{ Lauraceae } \\
\hline \multirow[t]{2}{*}{ Migukat } & Licaria martiniana (Mez) Kosterm. & MC.650 & $2 / 10$ & $0 / 3$ & $3 / 3$ \\
\hline & Ocotea percurrens Vicent. & Gr.1680 & $2 / 10$ & & \\
\hline Panawnap & Aiouea longipetiolata van der Werff & MC.155 & $2 / 5$ & $2 / 3$ & $3 / 3$ \\
\hline Sedri kamwi & Licaria martiniana (Mez) Kosterm. & CO.231 & $3 / 7$ & $1 / 4$ & $4 / 4$ \\
\hline \multirow[t]{2}{*}{ Wen } & Ocotea guianensis Aubl. & Gr.2068 & $7 / 8$ & $1 / 2$ & $2 / 2$ \\
\hline & Lauraceae sp. 3 & $\mathrm{CO} .170$ & $1 / 8$ & & \\
\hline \multicolumn{6}{|l|}{ Lecythidaceae } \\
\hline \multirow[t]{7}{*}{ Avun } & Eschweilera coriacea (DC.) S.A. Mori & Gr.Pr.1990 & $5 / 38$ & $5 / 6$ & $6 / 6$ \\
\hline & Lecythis persistens Sagot & $\mathrm{CO} .27$ & $5 / 38$ & & \\
\hline & Eschweilera grandiflora (Aubl.) Sandwith & MC.212 & $4 / 38$ & & \\
\hline & Eschweilera sagotiana Miers & CO.254 & $4 / 38$ & & \\
\hline & Eschweilera apiculata (Miers) A.C.Sm. & MC.116 & $3 / 38$ & & \\
\hline & Lecythis holcogyne (Sandwith) S.A. Mori & CO.148 & $3 / 38$ & & \\
\hline & Eschweilera chartaceifolia S.A. Mori & MC.321 & $2 / 38$ & & \\
\hline \multirow[t]{3}{*}{ Kwatri waxriune (seyne) } & Lecythis poiteaui $\bigcirc$. Berg & Co.19 & $6 / 21$ & $3 / 3$ & $3 / 3$ \\
\hline & Eschweilera cf. simiorum (Benoist) Eyma & CO.160 & $3 / 21$ & & \\
\hline & Eschweilera chartaceifolia S.A. Mori & MC.60 & $2 / 21$ & & \\
\hline \multicolumn{6}{|l|}{ Leguminosae } \\
\hline Ãjelik & Dicorynia guianensis Amshoff & Gr.3057 & $10 / 10$ & $3 / 3$ & $3 / 3$ \\
\hline Kaybune ã & Zygia racemosa (Ducke) Barneby \& J.W. Grimes & CO.4 & $3 / 3$ & $1 / 1$ & $1 / 1$ \\
\hline \multirow[t]{3}{*}{ Miumiu } & Inga paraensis Ducke & Gr.3175 & $3 / 13$ & $1 / 3$ & $3 / 3$ \\
\hline & Inga capitata Desv. & Gr.JLG.3216 & $2 / 13$ & & \\
\hline & Inga sp. 15 & CO.332 & $2 / 13$ & & \\
\hline
\end{tabular}


Table 5 Botanical names of the most frequently collected species (Continued)

\begin{tabular}{|c|c|c|c|c|c|}
\hline \multirow{2}{*}{$\begin{array}{l}\begin{array}{l}\text { Botanic family } \\
\text { (main palikur name) }\end{array} \\
\text { Sakeg (kamwi) }\end{array}$} & \multirow{2}{*}{$\begin{array}{l}\text { Botanical name }^{a} \\
\text { Hymenolobium flavum Kleinhoonte }\end{array}$} & \multirow{2}{*}{$\begin{array}{l}\begin{array}{l}\text { Reference voucher } \\
\text { specimen }^{\text {b }}\end{array} \\
\text { Gr.3067 }\end{array}$} & \multirow{2}{*}{$\begin{array}{l}\text { Correspondence botanical } \\
\text { species/ethnospecies } \\
2 / 13\end{array}$} & \multicolumn{2}{|c|}{ Fidelity level of use } \\
\hline & & & & $0 / 2$ & $2 / 2$ \\
\hline & Parkia nitida Miq. & Gr.3030 & $2 / 13$ & & \\
\hline$\tilde{A}$ danõ & Bocoa prouacensis Aubl. & Gr.3269 & $5 / 5$ & $0 / 2$ & $2 / 2$ \\
\hline Wakap & Vouacapoua americana Aubl. & Gr.3011 & $16 / 16$ & $4 / 4$ & $2 / 4$ \\
\hline \multirow[t]{4}{*}{ Wap } & Eperua falcata Aubl. & CO.52 & $4 / 12$ & $4 / 4$ & $4 / 4$ \\
\hline & Dialium guianense (Aubl.) Sandwith & Gr.1766 & $2 / 12$ & & \\
\hline & Eperua grandiflora (Aubl.) Benth. & Gr.3082 & $2 / 12$ & & \\
\hline & Macrolobium bifolium (Aubl.) Pers. & Gr.1662 & $2 / 12$ & & \\
\hline Yuhumwi & Pentaclethra macroloba (Willd.) Kuntze & Gr.1643 & $3 / 5$ & $1 / 1$ & $1 / 1$ \\
\hline \multirow[t]{2}{*}{ Wakukwa adava } & Gustavia augusta $\mathrm{L}$. & MFP.1365 & $4 / 8$ & $1 / 1$ & $1 / 1$ \\
\hline & Lecythis zabucajo Aubl. & Gr.3078 & $2 / 8$ & & \\
\hline \multicolumn{6}{|l|}{ Melastomataceae } \\
\hline \multirow[t]{2}{*}{ Ahayumna } & Mouriri nervosa Pilg. & Gr.3153 & $6 / 8$ & $3 / 5$ & $5 / 5$ \\
\hline & Mouriri francavillana Cogn. & L.836 & $2 / 8$ & & \\
\hline \multirow[t]{2}{*}{ Avitkat } & Mouriri francavillana Cogn. & DD.14 & $3 / 5$ & $1 / 3$ & $3 / 3$ \\
\hline & Mouriri crassifolia Sagot & CO.323 & $2 / 5$ & & \\
\hline Timuvukti & Mouriri sagotiana Triana & Gr.1627 & $7 / 8$ & $0 / 3$ & $3 / 3$ \\
\hline \multicolumn{6}{|l|}{ Moraceae } \\
\hline Impitit waxriune & Maquira guianensis Aubl. & CO.311 & $3 / 4$ & $0 / 1$ & $1 / 1$ \\
\hline \multirow[t]{3}{*}{ Pairi } & Brosimum rubescens Taub. & CO.172 & $6 / 16$ & $1 / 2$ & $2 / 2$ \\
\hline & Brosimum guianense (Aubl.) Huber ex Ducke & MC.6 & $3 / 16$ & & \\
\hline & Trymatococcus oligandrus (Benoist) Lanj. & Gr.3143 & $3 / 16$ & & \\
\hline Pakaad & Bagassa guianensis Aubl. & Gr.1655 & $2 / 2$ & $1 / 1$ & $1 / 1$ \\
\hline \multirow[t]{3}{*}{ Tukwangu } & Helicostylis tomentosa (Poepp. \& Endl.) J.F.Macbr. & MC.508 & $2 / 7$ & $0 / 2$ & $2 / 2$ \\
\hline & Naucleopsis guianensis (Mildbr.) C.C. Berg & Gr.3148 & $2 / 7$ & & \\
\hline & Pseudolmedia laevis (Ruiz \& Pav.) J.F.Macbr. & CO.227 & $2 / 7$ & & \\
\hline \multicolumn{6}{|l|}{ Myristicaceae } \\
\hline \multirow[t]{6}{*}{ Wahusi (waxriune) } & Virola michelii Heckel & Gr.3036 & $7 / 20$ & $0 / 3$ & $3 / 3$ \\
\hline & Iryanthera hostmannii (Benth.) Warb. & Gr.1754 & $3 / 20$ & & \\
\hline & Iryanthera sagotiana (Benth.) Warb. & Pr.Gr.4392 & $3 / 20$ & & \\
\hline & Virola kwatae Sabatier & MC.20 & $2 / 20$ & & \\
\hline & Virola multicostata Ducke & MC.417 & $2 / 20$ & & \\
\hline & Virola surinamensis (Rol. ex Rottb.) Warb. & DD.15 & $2 / 20$ & & \\
\hline \multicolumn{6}{|l|}{ Myrtaceae } \\
\hline Awaw & Myrciaria floribunda (H. West ex Willd.) O. Berg & Gr.3002 & $4 / 9$ & $2 / 3$ & $3 / 3$ \\
\hline \multirow[t]{4}{*}{ Inam etni } & Eugenia coffeifolia DC. & CO.287 & $6 / 22$ & $4 / 5$ & $5 / 5$ \\
\hline & Eugenia patrisii Vahl & Gr.3091 & $3 / 22$ & & \\
\hline & Myrcia decorticans DC. & MC.49 & $3 / 22$ & & \\
\hline & Eugenia sp.FG13 (Holst) & MC.77 & $2 / 22$ & & \\
\hline Kagegut & Myrcia fallax (Rich.) DC. & Gr.1802 & $2 / 3$ & $1 / 1$ & $1 / 1$ \\
\hline \multicolumn{6}{|l|}{ Ochnaceae } \\
\hline \multirow[t]{2}{*}{ Kwatri waxriune (duwõ) } & Lacunaria cf. jenmanii (Oliv.) Ducke & CO.353 & $2 / 6$ & $1 / 1$ & $1 / 1$ \\
\hline & Quiina sessilis Choisy & MC.503 & $2 / 6$ & & \\
\hline
\end{tabular}


Table 5 Botanical names of the most frequently collected species (Continued)

\begin{tabular}{|c|c|c|c|c|c|}
\hline \multirow{2}{*}{$\begin{array}{l}\text { Botanic family } \\
\text { (main palikur name) } \\
\text { Olacaceae }\end{array}$} & \multirow[t]{2}{*}{ Botanical name ${ }^{a}$} & \multirow[t]{2}{*}{$\begin{array}{l}\text { Reference voucher } \\
\text { specimen }^{b}\end{array}$} & $\begin{array}{l}\text { Correspondence botanical } \\
\text { species/ethnospecies }\end{array}$ & \multicolumn{2}{|c|}{ Fidelity level of use $e^{c}$} \\
\hline & & & & & \\
\hline Aneku & Ptychopetalum olacoides Benth. & CM.1060 & $5 / 5$ & $0 / 1$ & $1 / 1$ \\
\hline Yawu & Minquartia guianensis Aubl. & Gr.3007 & $5 / 5$ & $5 / 5$ & $0 / 5$ \\
\hline \multicolumn{6}{|l|}{ Rubiaceae } \\
\hline \multirow[t]{2}{*}{ Ã wakaha } & Ferdinandusa paraensis Ducke & MC.480 & $1 / 2$ & $0 / 1$ & $1 / 1$ \\
\hline & Ferdinandusa sp. 1 & CO.299 & $1 / 2$ & & \\
\hline Kinuwup & Duroia eriopila L.f. & Gr.1760 & $2 / 4$ & $1 / 2$ & $1 / 2$ \\
\hline \multicolumn{6}{|l|}{ Sapindaceae } \\
\hline \multirow[t]{2}{*}{ Mbagwi } & Cupania scrobiculata Rich. & CO.147 & $4 / 9$ & $0 / 2$ & $2 / 2$ \\
\hline & Matayba sp. undet & MC.235 & $2 / 9$ & & \\
\hline \multirow[t]{5}{*}{ Tuu } & Talisia carinata Radlk. & Gr.1585 & $1 / 5$ & $0 / 3$ & $3 / 3$ \\
\hline & Talisia megaphylla Sagot & Gr.1753 & $1 / 5$ & & \\
\hline & Talisia mollis Kunth ex Cambess. & CO.185 & $1 / 5$ & & \\
\hline & Talisia sp. undet & MC.588 & $1 / 5$ & & \\
\hline & Toulicia elliptica Radlk. & L.788 & $1 / 5$ & & \\
\hline \multicolumn{6}{|l|}{ Sapotaceae } \\
\hline Balata (duwõ) & Manilkara huberi (Ducke) A. Chev. & Gr.3035 & $3 / 4$ & $2 / 2$ & $2 / 2$ \\
\hline \multirow[t]{4}{*}{ Kuyaw kamwi } & Pouteria decorticans T.D. Penn. & MC.83 & $23 / 36$ & $6 / 6$ & $6 / 6$ \\
\hline & Pouteria gongrijpii Eyma & Pr.Gr.4277 & $7 / 36$ & & \\
\hline & Pouteria filipes Eyma & Gr.3177 & $2 / 36$ & & \\
\hline & Pouteria singularis T.D.Penn. & MC.160 & $2 / 36$ & & \\
\hline Tukuyuy kamwi & Pouteria jariensis Pires \& T.D.Penn. & Gr.3183 & $2 / 4$ & $2 / 2$ & $2 / 2$ \\
\hline \multirow[t]{12}{*}{ Uu kamwi } & Micropholis cayennensis T.D.Penn. & Gr.3059 & $5 / 56$ & $8 / 8$ & $8 / 8$ \\
\hline & Pouteria gongrijpii Eyma & Pr.Gr.4293 & $5 / 56$ & & \\
\hline & Pouteria torta (Mart.) Radlk. & CO.106 & $5 / 56$ & & \\
\hline & Pouteria rodriguesiana Pires \& T.D.Penn. & Gr.3130 & $4 / 56$ & & \\
\hline & Pouteria guianensis Aubl. & CO.252 & $4 / 56$ & & \\
\hline & Pouteria aubrevillei Bernardi & MC.108 & $3 / 56$ & & \\
\hline & Pouteria decorticans T.D. Penn. & $\mathrm{CO} .33$ & $3 / 56$ & & \\
\hline & Pouteria macrocarpa (Mart.) D.Dietr. & CO.111 & $3 / 56$ & & \\
\hline & Pouteria singularis T.D.Penn. & CO.290 & $3 / 56$ & & \\
\hline & Micropholis guyanensis (A.DC.) Pierre & Gr.1749 & $2 / 56$ & & \\
\hline & Pouteria hispida Eyma & CO.154 & $2 / 56$ & & \\
\hline & Pouteria reticulata (Engl.) Eyma & MC.699 & $2 / 56$ & & \\
\hline \multicolumn{6}{|l|}{ Siparunaceae } \\
\hline Avakni avak & Siparuna pachyantha A.C. Sm. & Gr.3172 & $2 / 2$ & $1 / 1$ & $1 / 1$ \\
\hline \multirow[t]{2}{*}{ Yahiwemna } & Siparuna cristata (Poepp. \& Endl.) A.DC. & CO.284 & $3 / 6$ & $0 / 1$ & $1 / 1$ \\
\hline & Siparuna guianensis Aubl. & Gr.1850 & $2 / 6$ & & \\
\hline
\end{tabular}

${ }^{\mathrm{a}}$ In bold, the most representative species

${ }^{\mathrm{b}}$ Deposited at the CAY herbarium, French Guiana

${ }^{\mathrm{C}}$ Ratio calculated as the no. of given botanic species vouchers/total vouchers for this ethnospecies (total vouchers 669). Fidelity level of use is calculated according to [23]

for buildings that last longer than the former houses, which have a 15-year lifespan. Nails and corrugated iron roofs are thus increasingly replacing lashing and $M$. saccifera palm thatch. The second is pressure on the natural resources as emblematic species, for example, $V$. americana posts are said to be becoming rarer. The 
Table 6 Thatch and latch materials

\begin{tabular}{lll}
\hline Botanic family & Palikur name & Botanic determination (herbarium voucher no.) \\
\hline Cyclanthaceae & Akuywa & Thoracocarpus bissectus (Vell.) Harling (DD.11) \\
Marantaceae & Wevri & Ischnosiphon obliquus (Rudge) Körn. (DD.16) \\
Araceae & Tiravui & Heteropsis flexuosa (Kunth) G.S.Bunting (Gr.JLG.3231) \\
Arecaceae & Tuuvan & Manicaria saccifera Gaertn. \\
& Isaw & Mauritia flexuosa L.f. \\
& Issuvan & Geonoma baculifera (Poit.) Kunth \\
\end{tabular}

${ }^{\mathrm{a}}$ Species not collected for herbarium voucher in this project

logistic effort and the need for a pick-up to harvest building material is greater today. Timber wood, which is more accessible, has become an attractive option. More than just the esthetic dimension, these changes imply a real loss of ecological knowledge and technological know-how. As it has been observed for basketry [15], social changes and schooling may explain the decrease in knowledge transmission.

\section{Wood selection}

Despite the many changes to roundwood housing, the Palikur still have vast knowledge of the materials used in traditional building. Our quantitative results reveal clear preferences for particular species depending on the planned use, with selection based on technical criteria, above all durability. Durability is the most important requirement for woods used for posts, due to their higher exposure. A comparison of our results with reports in the literature underlines the similarities in the characteristics of construction wood among many Amazonian Amerindians [5, 11, 17, 42-44, 52, 56].

\section{Posts}

Like the Palikur, the Brazilian Waimiri-Atroari make posts from Minquartia guianensis (Olacaceae) [44, 62] due to its very high resistance to rot and to xylophagous insects. Its use is also mentioned among the Shuar [8] and the Cayapa in Ecuador [6] and by the Boni Maroons in French Guiana [21]. This species is so highly valued for posts among the Brazilian Tembé and Ka'apor that burning it is prohibited, with a risk of death in the village [55]. This wood is so durable that remains of $M$. guianensis posts were found in a more than 3000-yearold pre-Columbian house discovered at an archeological site [59]. Woods used for posts by the Yanomami are not the same as the wood preferred by the Palikur, but the two use the same criteria, durability, and resistance. The main species are Manilkara huberi and various Pouteria spp. (Sapotaceae), also used as a second choice by the Waimiri-Atroari and are occasionally used by the Palikur, as well as Centrolobium paraense (Leguminosae) [42]. The use of the long-lasting wood of $V$. americana and of Pouteria decorticans for posts is also mentioned among Boni Maroons [21]. The wood of some species belonging to the families Chrysobalanceae and Lecythidaceae is found among the Bolivian Tsimane' (Hirtella spp. and Licania spp.) [56], the Kalin'a in Guyana (Couepia spp., Eschweilera spp. and Lecythis spp.) [65], or as a substitute for M. guianensis among the Waimiri-Atroari (several Licania and Eschweilera including E. coriacea). Yanomami also use the genus Couepia for secondary posts [43] also occasionally used by the Palikur. Surprisingly, the Palikur appear to not use Myrtaceae much. The wood of these trees is extremely hard and is favored for the thin external posts in roundhouses in the Guiana shield highlands where the Yanomami live and where the Myrtaceae family is very common [43]. The fact that this family, which is used by the Teko in French Guiana (Odonne and Davy, unpublished data) and by the Kali'na (Grenand, unpublished data), was rarely cited by the Palikur could be due to their low density in the study area.

\section{Beams and rafters}

Like the Palikur, the Yanomami and Waimiri-Atroari also preferentially use the Annonaceae wood (Xylopia spp., Guatteria spp., Duguetia spp.) for frames [42-44]. The trees belonging to this family are considered to make straight, long range beams. Xylopia species are actually described as following the Roux architectural model, with an orthotropic, slender trunk, few ramifications, and plagiotropic branches [37, 49], and are therefore a very good building wood. The wood of the genera Eschweilera (Lecythidaceae) and Pouteria (Sapotaceae) is also used for beams by the Waimiri-Atroari [44]. Urubu Ka'apor use a wide array of species for the framework, i. e., Pouteria spp., Duguetia spp., Guatteria spp., Licania spp., and Eschweilera spp., but prefer the durable wood of Licania (Chrysobalanceae) or Eschweilera species due to their resistance to xylophagous insects [5]. In Bolivia, the Tacana also select Annonaceae (Guatteria spp., Unonopsis spp., Xylopia spp.) and Chrysobalanceae (Hirtella spp. and Licania spp.) for beams and rafters [17], as do the Caboclo from the Capim River in Brazil [62]. In Guyana, the wood of several Annonaceae (Xylopia spp., Anaxagorea spp., Duguetia spp., Guatteria spp., and 
Unonopsis spp.) is also appreciated for the framework, as are those of Eschweilera or Lecythis species, but to a lesser extent [65].

\section{Convergence of evidence-based technological knowledge} These similarities suggest a convergence that could be due to some technological properties of the species. This is illustrated by the high resistance against rot and xylophagous insects of the species used for the posts, for which the quality of the material is more important. The use of Xylopia and Pseudoxandra genera for beams or rafters throughout Amazonia is explained by their straight shape, resistance (poorly documented), and easy debarking. This last criterion might seem above all esthetic, but the Palikur explicitly mentioned that debarked wood is more resistant to xylophagous insects. Whether related to technological factors or not, this propensity for easily peeled woods throughout Amazonia is a very distinctive illustration of cultural convergence. Laboratory tests are desirable to understand these cultural selection processes [57].

The similarities are even more striking in lashing materials. Aerial roots of Heteropsis spp. are the most widely used lashing material in Amazonian buildings [5, 8, 19, 21, 29, 42, 44, 65] and are more extensively used than the second choice $T$. bissectus [42, 48, 56, 65]. There is less consensus for roof thatching, as aside from the Palikur, only the Arawak in Guyana also use $M$. saccifera palms [65], very likely due to the limited geographical distribution of this species, which is mainly restricted to the swamps and low drainage areas of the Guiana shield [26]. The use of Geonoma palms as thatching material (here G. baculifera) is much more widespread in Amazonia $[5,21$, $22,29,42,48,56,65,66]$.

\section{Resource availability}

The availability of a resource inevitably influences its use. For example, many Amazonian groups decide on the location of a village based on the availability of "stationary" resources, such as thatching material. Testing whether the use of some species depends on their availability for building would have required extensive botanical inventories around Regina and Saint-Georges de l'Oyapock, so we will limit our discussion here to conjecture. Nevertheless, the influence of the availability of a species appears to depend to a great extent on the type of building planned: a light building with a projected life span of 2 or 3 years, in a slash and burn field, for example, will be preferentially built using species that grow in the immediate vicinity despite their inferior quality. On the other hand, a permanent collective building, with more social value, will be the object of a more rigorous material selection. The fine analysis of the balance between quality and availability would need more detailed research.

Hyper-dominance of trees belonging to the Lecythidaceae family and their pan-Amazonian distribution (including Eschweilera coriacea) is certainly one of the factors that explain their frequent use for building by the Palikur and other Amazonian peoples [64]. The Annonaceae family, held in high esteem for the framework, is also abundant throughout Amazonia. Moreover, several species of Guatteria and Xylopia (also used for the framework by the Wayãpi in French Guiana) are fostered by anthropization and are thus found close to the villages located in secondary forests [30, 65].

\section{Why does roundwood building persist?}

Although housing has undergone significant changes, many communities are willing to conserve traditional buildings or to start using them again for ceremonial functions, as a way to claim their cultural identity, by the practice of rituals, dances, and craftwork, and as a place of social networking and community building, even if some authors consider that these activities previously took place outdoors [46]. Today, activities such as basketry, music, or dances are important ways to affirm their identity among French Guiana Amerindians [15].

Simultaneously, the Palikur have become aware of the mismatch between modern housing and their traditional way of life [10]. Roundwood buildings provide natural ventilation, lowering the high tropical temperatures and the ambient moisture. Their low cost is also an advantage for people who only have a limited income. The esthetic dimension of these buildings should not be ignored, nor is the well-being they insure through the creation of social ties. The people we interviewed did not think modern housing is well suited to the still largely collective way of life of the Palikur.

The loss of knowledge observed in some cases is offset by regular exchanges between the Palikur in French Guiana and in Brazil, the latter often being perceived as more skillful and knowledgeable about cultural and natural aspects. In French Guiana, the Palikur still maintain strong interactions with the forest, as $71 \%$ of people interviewed by Sevelin-Radiguet [60] said they go hunting regularly, 65\% harvest woody forest products, and $88 \%$ harvest non-woody products. Although unemployment may encourage these practices as alternative sources of income, they more likely reflect the persistence of the former way of life that was closer to nature.

\section{Conclusions}

From an ethnobotanical point of view, the Palikur use only a small fraction of the ca. 1600 ligneous species 
present in French Guiana [45]. This is evidence for the existence of rigorous selection criteria, technological as much as cultural. For posts, hard woods are preferred, as they are known to be resistant to rot and to xylophage activity, which are key requirements for durability, since the posts are in direct contact with the ground and the framework weighs hundreds of kilograms. The yawu, Minquartia guianensis, and the wakap, Vouacapoua americana, are their emblematic species, followed by many Lecythidaceae, Leguminosae, and Sapotaceae also observed on both sides of the Amazon for this use, testifying to a consensus in technical selection criteria among Amazonian Amerindians. The main species used for the framework belong to the Annonaceae family, genera Xylopia, Guatteria, or Duguetia. Lecythidaceae, and notably the Eschweilera genus, are also highly esteemed as elsewhere in Amazonia. The technical properties of these woods, and notably their use as roundwood, remain to be analyzed. It is nevertheless highly probable that a long-term selection process led to the identification of species that combine useful mechanical properties, high resistance against rot and xylophage activity, and ease of use during construction. The ease of stripping the bark from the trunk is one of the most important criteria. Combining the useful with the pleasant, this technical and esthetic choice echoes the selection of fluted trunks, which are said to be nicer, for posts.

The choice between abundance in the vicinity and technical criteria appears to depend on the planned use of the building. Woods are selected much more carefully for long-lasting buildings, although they often require more complex logistics. Today, this is offset by the increasing use of squared timber, as species that were difficult or impossible to use as roundwood are now more easily available. Understanding these trade-offs more precisely would require a more precise survey focused on the one hand on the abundance and ecological distribution of available species (both those used as roundwood and those used as square timber) and on the other hand on the criteria of choice that influence construction processes.

From a socio-cultural point of view, the persistence of roundwood houses is first explained by the attachment of the Palikur to the comfort they provide in a tropical climate. Their low construction cost and esthetic considerations are nevertheless equally cited. Continuing to build roundwood houses and going into the forest to harvest useful materials for their construction may also be a way for the Palikur to claim their cultural identity by asserting their indigenousness and the superiority of a particular way of life. Like other cultural activities, such as basketry, highly esteemed by the Palikur [15], maintaining these century-old practices is a form of cultural resistance against a modern world prone to imposing its technical standards.

\section{Additional file}

Additional file 1: Full list of ethnospecies and their botanic correspondences. (DOCX $217 \mathrm{~kb}$ )

\section{Acknowledgements}

Our thanks go to all the members of the Palikur population involved in this project and who helped us in the collation and transcription of their knowledge. Among them, Antonio Narcisso, Jean Yapara, Louis Norino, and Georges Labonté were particularly helpful. The traditional Palikur chiefs of SaintGeorges de l'Oyapock kindly allowed this study to be performed and are acknowledged here for their support throughout the project. Bernard Thibaut, a wood scientist at CNRS, consistently helped us structure the manuscript.

\section{Funding}

This work was carried out in the context of the Observatoire Hommes-Milieux Oyapock (CNRS-OHM Oyapock) and was supported by "Investissement d'Avenir" grants managed by the Agence Nationale de la Recherche (Labex DRIIHM/IRDHEI and Labex CEBA: ANR-10-LABX-25-01). It was also supported by the Mission pour I'Interdisciplinarité of the French CNRS.

\section{Availability of data and materials}

All the data generated during this study are included in this published article [and its supplementary information files]. A full list of taxa collected is available as a supplementary data file.

\section{Authors' contributions \\ $\mathrm{DD}, \mathrm{GO}, \mathrm{BC}, \mathrm{JB}$, and $\mathrm{CO}$ designed the study. $\mathrm{CO}, \mathrm{GO}$, and $\mathrm{AC}$ conducted the field survey. JE, CO, and GO performed the botanical identifications. PG compiled the previous ethnobotanical data. $A C, D D$, and $P G$ revised the Palikur taxonomy and spelling. GO drafted the manuscript. AC, PG, JB, BC, and DD revised the manuscript and gave critical inputs. All the authors read the final manuscript and agreed to its submission.}

\section{Ethics approval and consent to participate}

The traditional Palikur chiefs of Saint-Georges de l'Oyapock were consulted at the beginning of the study, and we were given their prior informed verbal consent as a working authorization. They were regularly informed of the progress of the project.

Herbarium vouchers were collected in national forest of "Régina-SaintGeorges de I'Oyapock" with the authorization of the French National Forestry Office (ONF) (no. 140523_02/MH/ML).

\section{Consent for publication}

In September 2017, the traditional Palikur chiefs of Saint-Georges de I'Oyapock were consulted to obtain their agreement concerning the publication of the results.

\section{Competing interests}

The authors declare that they have no competing interests.

\section{Publisher's Note}

Springer Nature remains neutral with regard to jurisdictional claims in published maps and institutional affiliations.

\section{Author details}

${ }^{1}$ LEEISA (Laboratoire Ecologie, Evolution, Interactions des Systèmes Amazoniens), CNRS, Université de Guyane, IFREMER, 275 route de Montabo, 97300 Cayenne, France. ${ }^{2}$ CNRS, UMR Ecologie des Forêts de Guyane (EcoFoG), AgroParisTech, Cirad, INRA, Université des Antilles, Université de Guyane, 97310 Kourou, France. ${ }^{3}$ LLL, Laboratoire Ligérien de Linguistique, UMR 7270, Université d'Orléans, 45065 Orléans, France. ${ }^{4}$ ICTB (International Center for Tropical Botany, Department of Biological Sciences), Florida 
International University, Miami, FL 33199, USA. ${ }^{5}$ AMAP, IRD, CIRAD, CNRS, Université de Montpellier, INRA, Boulevard de la Lironde, TA A-51/PS2, F-34398, Montpellier Cedex 5, France. ${ }^{6}$ CIRAD, UMR Ecologie des Forêts de Guyane (EcoFoG), AgroParisTech, Cirad, INRA, Université des Antilles, Université de Guyane, 97310 Kourou, France.

Received: 26 September 2017 Accepted: 28 March 2018 Published online: 24 April 2018

\section{References}

1. Ahlbrinck W. Encyclopaedie der Karaïben. Koninklijke Academie van Wetenschappen, Afdeeling Letterkunde. Nieuwe reeks, Deel XXVII, No 1, Amsterdam, the Netherlands. 1931. p. 544

2. Angiosperm Phylogeny Group. An update of the angiosperm phylogeny group classification for the orders and families of flowering plants: APG IV. Bot J Linn Soc. 2016;181:1-20.

3. Arhem K. From longhouse to village: structure \& change in the Colombian Amazon. In: Rival LM, Whitehead NL, editors. Beyond the visible and the material: the amerindianization of society in the work of Peter Rivière. Oxford: Oxford University Press; 2001. p. 123-158.

4. Balée W. A Etnobotânica Quantitativa dos Índios Tembé (Rio Ourupi, Pará). Boletim do Museu Paraense Emilio Goeldi Série Botanica. 1987;2:29-50.

5. Balée W. Footprints of the forest: Ka'apor ethnobotany-the historical ecology of plant utilization by an Amazonian people. New York: Columbia University Press; 1994. 396p.

6. Barfod A, Kvist L. Comparative Ethnobotanical Studies of the Amerindian Groups in Coastal Ecuador. Copenhagen: Det Kongelige Danske Videnskabernes Selskab Editor; 1996. p. 166.

7. Barret, J., 2001. Atlas illustré de la Guyane. ORSTOM Edition, Cayenne, French Guiana. 215p.

8. Bennett B, Baker M, Gomez Andrade P. Ethnobotany of the Shuar of eastern Ecuador. In: Advances in economic botany $N^{\circ} 14$. New York: The New York Botanical Garden Press; 2002. p. 302

9. Berlin B. Ethnobiological classification: principles of categorization of plants and animals in traditional societies. Princeton: Princeton University Press; 1993. p. 354.

10. Bianchi J. Mode de vie traditionnels et modernisme dans l'habitat en Guyane, Rapport d'étude; 2002. p. 27.

11. Boom B. Ethnobotany of the Chácobo Indians, Beni, Bolivia. Adv Econ Bot. 1987;4:1-69.

12. Boom B. Useful plants of the Panare Indians of the Venezuelan Guayana. Adv Econ Bot. 1990;8:57-76.

13. Boudoux d'Hautefeuille M. La route, facteur de développement socioéconomique? Une analyse des enjeux portés par les projets routiers en Guyane française. Espaces et Sociétés. 2014;156-157:177-195.

14. Boyle B, Hopkins N, Lu Z, Raygoza Garay JA, Mozzherin D, Rees T, Matasci N, Narro ML, Piel WH, Mckay SJ, Lowry S, Freeland C, Peet RK, Enquist BJ. The taxonomic name resolution service: an online tool for automated standardization of plant names. The taxonomic name resolution service [Internet]. iPlant collaborative. Version 4.0 [lastly accessed: 04/03/2017]. http://tnrs.iplantcollaborative.org. BMC Bioinformatics. 2013;14:1-15. https:// doi.org/10.1186/1471-2105-14-16.

15. Davy D. Vannerie et vanniers: Approche ethnologique d'une activité artisanale en Guyane française, Thèse de doctorat de I'Université d'Orléans; 2007. p. 527.

16. Davy, D., 2015. Aroumans-Ressource et usages des Amérindiens du sud de la Guyane. Guianensis, les carnets du Parc Amazonien de Guyane. Parc amazonien de Guyane Edition, Cayenne, French Guiana. 76p.

17. DeWalt S, Bourdy G, Chavez De Michel L, Quenevo C. Ethnobotany of the Tacana: quantitative inventories of two permanent plots of northwestern Bolivia. Econ Bot. 1999;53(3):237-260.

18. Dubois JC. Uses of wood and non-wood forest products by Amazon forest dwellers. Unasylva. 1996;47:8-15.

19. Duke JA, Vasquez R. Amazonian ethnobotanical dictionary. Boca Raton: CRC Press; 1994. 215p.

20. Fénelon Costa, M. H., Malhano, M. H., 1986. A habitação indígena brasileira. In: Ribeiro, B. G., \& Ribeiro, D. (Coord.). Suma etnológica brasileira: tecnologia indígena (Vol. 2). Vozes Edition, Petrópolis, Brazil: 27-92.

21. Fleury M. "Busi-nenge": les Hommes-Forêt, essai d'ethnobotanique chez les Aluku (Boni) en Guyane française, Thèse de doctorat de l'Université Paris Vl; 1991. p. 357.
22. Fleury, M., Davy, D., Grenand P., 2014. Des palmiers et des Hommes. In: de Granville J.- J. \& Gayot M. (Eds), Guide des palmiers de Guyane, ONF Editions, Cayenne, French Guiana: 50-81.

23. Friedman J, Yaniv Z, Dafni A, Palewitch D. A preliminary classification of the healing potential of medicinal plants, based on a rational analysis of an ethnopharmacological field survey among Bedouins in the Negev Desert, Israel. J Ethnopharmacol. 1986;16:275-287.

24. Gallois C. Wajãpi rena : roças, pátios e casas. Rio de Janeiro: Museu do Índio, São Paulo; 2002. p. 94

25. Gasché J. L'habitat witoto: "progrès" et tradition. Journal de la Société des Américanistes. 1972:61:177-214.

26. Granville, J.-J. de, Gayot, M., 2014. Guide des palmiers de Guyane, ONF Editions, Cayenne, French Guiana. 274p.

27. Grenand, F., 2009. Encyclopédies palikur, wayana \& wayapi. Langue, milieu et histoire. Éditions du Comité des travaux historiques et scientifiques/Presses universitaires d'Orléans, Paris/Orléans. 118p.

28. Grenand F. Enjeux de territoire sur une frontière méconnue, entre la France et le Brésil: le fleuve Oyapock. Confins. 2012;16:7961.

29. Grenand, P., 1980. Introduction à l'étude de l'univers Wayãpi: ethnoécologie des indiens du Haut-Oyapock (Guyane-française). SELAF Editions, Paris. 332p.

30. Grenand $P$. The use and cultural significance of the secondary forest among the Wayapi Indians. In: Plotkin M, Famalore L, editors. Sustainable harvest and marketing of rain forest products. Sustainable harvest and marketing of rain forest product. Washington D.C.: Island Press; 1992. p. 27-40

31. Grenand P. De l'arc au fusil: Un changement technologique chez les Wayapi de Guyane. In: Grenand F, Randa V, editors. Transitions plurielles: exemples dans quelques sociétés des Amériques. Paris: Peeters Editions; 1995. p. 23-53.

32. Grenand P, Grenand F. La côte d'Amapa, de la bouche de I'Amazone à la baie d'Oyapock, à travers la tradition orale Palikur. Boletim do Museu Paraense Emilio Goeldi, Serie Antropologia. 1987;3(1):1-77.

33. Grenand, P., Moretti, C., Jacquemin, H., Prévost, M., 2004. Pharmacopées traditionnelles en Guyane: Créoles, Palikur, Wayãpi. IRD Editions, Paris, France. 816p.

34. Grenand P, Prévost M-F. Les plantes colorantes utilisées en Guyane française. Journal Agriculture Traditionnelle et de Botanique Appliquée. 1994;36:139-172.

35. Guitet, S., Brunaux, O., de Granville, J., Gonzalez, S., Richard-Hansen, C., 2015. Catalogue des habitats forestiers de Guyane. DEAL Guyane. 120p.

36. Guss D. To weave and sing: art symbol and narrative in the South America rain forests. Berkeley: University of California Press; 1989. p. 274.

37. Halle F, Oldeman RA, Tomlinson P. Tropical trees and forests-an architectural analysis. Berlin-Heidelberg-New York: Springer-Verlag; 1978. p. 442

38. Hurault J. La vie matérielle des noirs réfugiés Boni et des Indiens Wayana du Haut-Maroni (Guyane française): agriculture, économie et habitat. Paris: ORSTOM Editions; 1965. p. 142.

39. Lizot J. Aspects économiques et sociaux du changement culturel chez les Yanõmami. L'Homme. 1971;11(1):32-51.

40. Mattioni M. Palikurene: terre des Palicours. Pointe-à-Pitre: Centre universitaire des Antilles et de la Guyane; 1975. p. 115.

41. Medeiros MF, da Silva P, de Albuquerque U. Quantification in ethnobotanical research: an overview of indices used from 1995 to 2009. Sitientibus série Ciências Biológicas. 2011;11(2):211-230.

42. Milliken W, Albert B. The construction of a new Yanomami round-house. J Ethnobiol. 1997;17:215-234.

43. Milliken W, Albert B, Gomez GG. Yanomami: a forest people. Richmond: Kew Royal Botanic Gardens Press; 1999. p. 161.

44. Milliken W, Miller R, Pollard S, Wandelli E. Ethnobotany of the Waimiri Atroari Indians of Brazil. Richmond: Kew Royal Botanic Gardens Press; 1992. p. 146.

45. Molino, J.F., Sabatier, D., Prévost, M.F., Frame, D., Gonzalez, S., BilotGuérin, V., 2009. Etablissement d'une liste des espèces d'arbres de la Guyane française. Rapport d'étude de I'IRD. http://agriculture.gouv.fr/ telecharger/82277?token=3f22aa7c201d7af2b9ab3ad682b0a704. Accessed 4 Oct 2018.

46. Nimuendaju C. [1926] Les Indiens Palikur et leurs voisins. Éditions du Comité des travaux historiques et scientifiques. Orléans: Presses universitaires d'Orléans; 2008. p. 189 
47. Odonne G, Berger F, Stien D, Grenand P, Bourdy G. Treatment of leishmaniasis in the Oyapock basin (French Guiana): a K.A.P. survey and analysis of the evolution of phytotherapy knowledge amongst Wayãpi Indians. J Ethnopharmacol. 2011;137:1228-39.

48. Odonne G, Bourdy G, Ochoa Siguas N. Plantas medicinales y de otros usos de los Shawi. Lima: Concytec/Fondecyt/IRD Edition; 2014. p. 414.

49. Oldeman, R.A., 1974. L'architecture de la forêt guyanaise. Mémoire ORSTOM n $\mathrm{n}^{\circ} 73$, Paris

50. Pérez P. The architecture of the lower Oyapock Valley (French Guiana and Brazil). In: Piesik S, editor. Vernacular architecture: a new world survey. London: Thames and Hudson eds; 2014.

51. Phillips O, Gentry A, Reynel C, Wilkin P, Galvez-Durand B. Quantitative ethnobotany and Amazonian conservation. Conserv Biol. 1994;8:225-248.

52. Pilgram T. Environmental change and timber selection in Huambisa Jivaro house construction. Journal d'Agriculture Traditionnelle et de Botanique Appliquée. 1983;30:139-147.

53. Pinedo-Vasquez M, Zarin D, Jipp P, Chota-Inuma J. Use-values of tree species in a communal forest reserve in Northeast Peru. Conserv Biol. 1990;4:405-16.

54. Potte M-B. Manière d'habiter à Awala-Yalimapo. In Situ. 2003;2003-3:1283. https://doi.org/10.4000/insitu.1283.

55. Prance G, Balée W, Boom B, Carneiro R. Quantitative ethnobotany and the case for conservation in Amazonia. Conserv Biol. 1987;1:296-310.

56. Reyes-García V. Indigenous people, ethnobotanical knowledge, and market economy: a case study of the Tsimane' Amerindians in lowland Bolivia, PhD dissertation of the university of Florida; 2001. p. 273.

57. Rollet B. Intérêt de l'étude des écorces dans la détermination des arbres sur pied. Bois et Forêt des Tropiques. 1980;195:31-50.

58. Rossato S, De Leitão-Filho H, Begossi A. Ethnobotany of Caiçaras of the Atlantic forest coast (Brazil). Econ Bot. 1999;53:387-395.

59. Rostain S, de Saulieu G. La première maison d'Amazonie: le Formatif dans la province de Pastaza, Équateur. Journal de la Société des Américanistes. 2015;101:51-81.

60. Sevelin-Radiguet P. Usage et gestion du domaine forestier Régina/SaintGeorges, Guyane française, Mémoire de Master 2 de l'Université des Antilles et de la Guyane; 2011. p. 79.

61. Shackleton C, Delang C, Shackleton S. Non-timber forest products in the global context. Tropical Forestry. 2011;7:3-21.

62. Shanley $P$, Nelson A. Eroding knowledge: an ethnobotanical inventory in eastern Amazonia's logging frontier. Econ Bot. 2004;58:135-160.

63. Shanley P, Rosa N. Conhecimento em Erosão: Um Inventário Etnobotânico na Fronteira de Exploração da Amazônia Oriental—erosion knowledge: an ethnobotanical inventary in the exploration frontier of eastern Amazonia. Boletim do Museu Paraense Emílio Goeldi Série Ciências Naturais. 2005;1: 147-171.

64. ter Steege H, Pitman N, Sabatier D, Baraloto C, Salomão R, Guevara JE, Phillips OL, Castilho CV, Magnusson WE, Molino J-F, Monteagudo A, Núñez Vargas P, Montero JC, Feldpausch TR, Coronado ENH, Killeen TJ, Mostacedo B, Vasquez R, Assis RL, Terborgh J, Wittmann F, Andrade A, Laurance WF, Laurance SGW, Marimon BS, Marimon B-H, Guimarães Vieira IC, Amaral IL, Brienen R, Castellanos H, Cárdenas López D, Duivenvoorden JF, Mogollón HF, Matos FDDA, Dávila N, García-Villacorta R, Stevenson Diaz PR, Costa F, Emilio T, Levis C, Schietti J, Souza P, Alonso A, Dallmeier F, Montoya AJD, Fernandez Piedade MT, AraujoMurakami A, Arroyo L, Gribel R, Fine PV a, Peres C a, Toledo M, Aymard C,G, Baker TR, Cerón C, Engel J, Henkel TW, Maas P, Petronelli P, Stropp J, Zartman CE, Daly D, Neill D, Silveira M, Paredes MR, Chave J, Lima Filho DDA, Jørgensen PM, Fuentes A, Schöngart J, Cornejo Valverde F, Di Fiore A, Jimenez EM, Peñuela Mora MC, Phillips JF, Rivas G, van Andel TR, von Hildebrand P, Hoffman B, Zent EL, Malhi Y, Prieto A, Rudas A, Ruschell AR, Silva N, Vos V, Zent S, Oliveira A a, Schutz AC, Gonzales T, Trindade Nascimento M, Ramirez-Angulo $H$, Sierra R, Tirado M, Umaña Medina MN, van der Heijden G, Vela Cl a, Vilanova Torre E, Vriesendorp C, Wang O, Young KR, Baider C, Balslev H, Ferreira C, Mesones I, Torres-Lezama A, Urrego Giraldo LE, Zagt R, Alexiades MN, Hernandez L, Huamantupa-Chuquimaco I, Milliken W, Palacios Cuenca W, Pauletto D, Valderrama Sandoval E, Valenzuela Gamarra L, Dexter KG, Feeley K, Lopez-Gonzalez G, Silman MR. Hyperdominance in the Amazonian tree flora. Science. 2013;342:1243092.
65. van Andel, T., 2000. Non-timber forest products of the North-West district of Guyana. Part 1. \& Part 2. Tropenbos-Guyana Edition series 8B, Georgetown, Guyana. 326p. \& 348p.

66. Vickers W, Plowman T. Useful plants of the Siona and Secoya Indians of eastern Ecuador, Fieldiana, botany new series, №15. Chicago: Field Museum of Natural History Press; 1984. p. 63.

\section{Submit your next manuscript to BioMed Central and we will help you at every step:}

- We accept pre-submission inquiries

- Our selector tool helps you to find the most relevant journal

- We provide round the clock customer support

- Convenient online submission

- Thorough peer review

- Inclusion in PubMed and all major indexing services

- Maximum visibility for your research

Submit your manuscript at www.biomedcentral.com/submit
Biomed Central 